\title{
PHYTOCHEMICAL AND BIOLOGICAL STUDY OF ERANTHEMUM NERVOSUM (VAHL) R. BR., CULTIVATED IN EGYPT
}

\author{
Mahmoud H. Assaf ${ }^{1}$, Yaser G. Gouda ${ }^{1}$, Ehab S. El-Khayat ${ }^{2}$ and Reda A. Abd El-Hamid ${ }^{2}$ \\ ${ }^{1}$ Department of Pharmacognosy, Faculty of Pharmacy, Assiut University, Assiut, Egypt \\ ${ }^{2}$ Department of Pharmacognosy, Faculty of Pharmacy, Al-Azhar University, Assiut, Egypt
}

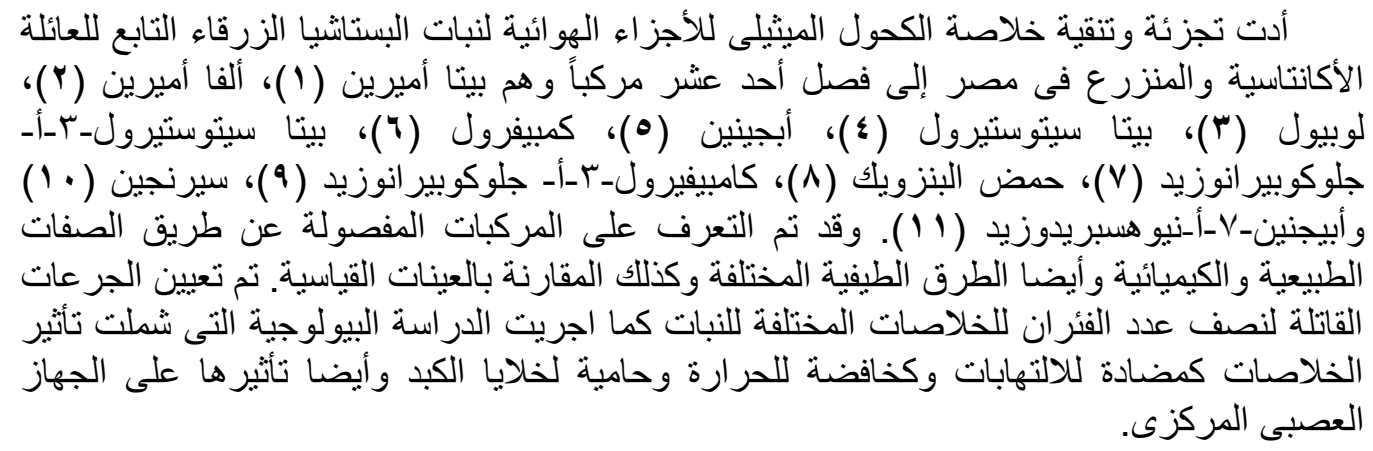

Fractionation and purification of the methanolic extract of the aerial parts of Eranthemum nervosum (Vahl) R. Br. (Acanthaceae) cultivated in Egypt yielded eleven compounds named: $\beta$ amyrin (1), $\alpha$-amyrin (2), Lupeol (3), $\beta$-sitosterol (4), Apigenin (5), Kaempferol (6), $\beta$-sitosterol 3-O- $\beta$-D-glucopyranoside (7), Benzoic acid (8), Kaempferol-3-O- $\beta$-D-glucopyranoside (9), Syringin (10) and Apigenin 7-O-neohesperidoside (11). Identification of these compounds has been established by physical, chemical and spectral data as well as comparison with authentic samples. The $L D_{50}$; anti-inflammatory; antipyretic; hepatoprotective and the effect on CNS were studied.

\section{INTRODUCTION}

Family Acanthaceae is one of the richest families with medicinal plants, comprising about 250 genera and 2500 species, distributed in tropics, Mediterranean regions, Australia, Central America, Brazil, Africa and IndoMalaysia $^{1-3}$. The genus Eranthemum contains 14 species $^{4}$ which are perennial tropical herbs, shrubs or sub-shrubs with blue or rose-coloured flowers, some of them are cultivated for their foliage and others for their flowers. Eranthemum nervosum (E. pulchellum $)^{4}$, cultivated in Egypt is one of these ornamentals. On reviewing current literature, no biological study for this plant could be traced while chemical investigation led to isolation of one iridoid (eranthemoside) ${ }^{5}$ and one alkaloid (3methoxy vasicinone) $)^{6}$. The present study is dealing with the isolation and identification of the chemical constituents in addition to the biological activities of the aerial parts of this plant.

\section{EXPERIMENTAL}

General: melting points were measured on Electrothermal 9100 Digital Melting Point Instrument (England Ltd., England). UV/visible spectral data were determined on JASCO Uvidec Model 320 spectrophotometer (Tokyo, Japan) and Ultrospec 1000, UV/visible Spectrometer, Pharmacia Biotech, Cambridge (England). IR spectra were recorded on Shimadzu IR-470 (Japan) spectrometer using $\mathrm{KBr}$ pellets. NMR spectra were measured on JEOL TNM-LA FT NMR spectrometer (Japan) using TMS as internal standard. EI-MS were recorded with JEOL JMS $600 \mathrm{~Hz}$ (Japan). Column chromatography was performed on Kieselgel 60 (60-230 mesh, Merck) and RP-18 (E-Merck, Germany), precoated silica gel $\mathrm{G}_{60} \mathrm{~F}_{254}$ and RP-18 plates for TLC (E-Merck, Germany) and Whatman sheets No. 1 (Whatman, Ltd., England) for paper chromatography. 


\section{Plant material}

The aerial parts of Eranthemum nervosum (Vahl) R.Br. were collected in the period from April to July 2004 from the Experimental Station of Faculty of Agriculture, Assiut University; the plant was kindly identified by Prof. Dr. Naeim El-keltawy, Department of Horticulture, Faculty of Agriculture, Assiut University. A voucher sample (No. 20102) was kept in the Herbarium of Faculty of Pharmacy, Assiut University, Assiut, Egypt.

\section{Extraction and isolation}

The air-dried powdered aerial parts of Eranthemum nervosum $(1.5 \mathrm{~kg})$ were exhaustively extracted by maceration in methanol (70\%). The methanolic extract was concentrated under reduced pressure to give dark green syrupy residue. The solvent-free residue $(150 \mathrm{~g})$ was subjected to fractionation using $n$-hexane, chloroform, ethyl acetate and $n$-butanol respectively till complete exhaustion and dried over anhydrous sodium sulphate yielding (40 g), (5 g), (15 g) and (25 g) for $n$ hexane, chloroform, ethyl acetate and $n$-butanol respectively.

Eight grams of the $n$-hexane fraction was chromatographed on silica gel $\mathrm{CC}$ using $n$ hexane-EtOAc gradient as eluting systems (fractions of $300 \mathrm{ml}$ were collected and the similar fractions were combined together) to give five fractions (F-I to F-V). F-II eluate (2 g) from $n$-hexane-EtOAc $(9.8: 0.2)$ was rechromatographed on silica gel $\mathrm{CC}$ using $n$ hexane-EtOAc gradient which afforded compounds $1(20 \mathrm{mg})$ and 2 (40 mg). F-III (1 g) eluted with $n$-hexane-EtOAc (9.5:0.5) afforded compound $3(15 \mathrm{mg})$ after repeated silica gel $\mathrm{CC}$ using $n$-hexane-EtOAc gradient. F-IV ( $2 \mathrm{~g}$ ) eluted with $n$-hexane-EtOAc (9:1) was also subjected to CC repeatedly using silica gel and $n$-hexane-EtOAc gradient as eluting systems which afforded compound 4 (55 mg).

The chloroform fraction (5 g) was chromatographed on silica gel column and eluted with $\mathrm{CHCl}_{3}-\mathrm{MeOH}$ (fractions of $100 \mathrm{ml}$ were collected) in gradient elution manner giving four fractions (F-I to F-IV). F-II (0.8 g), eluted with $\mathrm{CHCl}_{3}-\mathrm{MeOH}$ (9:1) was subjected to $\mathrm{CC}$ on silica gel and $\mathrm{CHCl}_{3}-\mathrm{MeOH}$ system gradient afforded compounds $5(40 \mathrm{mg})$ and $\mathbf{6}$ $(45 \mathrm{mg})$. F-III $(0.6 \mathrm{~g})$ and F-IV $(0.5 \mathrm{~g})$ eluted with $\quad \mathrm{CHCl}_{3}-\mathrm{MeOH} \quad(8.5: 1.5$ and 8:2) respectively were separately rechromatographed on silica gel columns using $\mathrm{CHCl}_{3}-\mathrm{MeOH}$ with gradient elution manner that afforded compounds 7 (120 mg) from F-III and $\mathbf{8}(50 \mathrm{mg})$ from F- IV.

The ethyl acetate fraction (15 g) was subjected to $\mathrm{CC}$ using silica gel and eluted with $\mathrm{CHCl}_{3}-\mathrm{MeOH}$ in gradient manner (fractions of $200 \mathrm{ml}$ were collected) giving five fractions (FI to F-V). F-II ( $0.3 \mathrm{~g})$ eluted with $\mathrm{CHCl}_{3}-\mathrm{MeOH}$ (8.5:1.5) afforded compound 9 (45 mg). F-III $(0.5 \mathrm{~g})$ eluted with $\mathrm{CHCl}_{3}-\mathrm{MeOH}(8: 2)$ was rechromatographed using RP-18 CC and 70\% $\mathrm{MeOH}$ in water as eluent afforded compound $10(10 \mathrm{mg})$ while F-V $(0.5 \mathrm{~g})$ eluted with $\mathrm{CHCl}_{3}-\mathrm{MeOH}(7: 3)$ afforded compound 11 (20 $\mathrm{mg}$ ) after re-column on RP-18 using 50\% $\mathrm{MeOH}$ in water.

\section{Acid hydrolysis}

About $10 \mathrm{mg}$ of compounds $\mathbf{9}$ and $\mathbf{1 1}$ were separately dissolved in $5 \mathrm{ml} \mathrm{MeOH}$ to which an equal volume of $10 \%$ sulphuric acid was added. The mixture was refluxed on a boiling water bath for 3 hrs. The hydrolyzate after cooling was shaken with ether $(3 \times 50 \mathrm{ml})$. The combined ethereal layer was distilled off and the aglycone was subjected to TLC and PC. The acidic mother liquor containing the sugar moiety(s) was neutralized with barium carbonate, concentrated and separately spotted alongside authentic sugars on Whatman No. 1 sheets using $n$-butanol-acetic acid-water (4:1:2 $\mathrm{v} / \mathrm{v}$ ) as a solvent system.

Compound (3): white needle crystals, m.p. 215-216 ${ }^{\circ} \mathrm{C} .{ }^{1} \mathrm{H}-\mathrm{NMR}\left(500 \mathrm{MHz}, \mathrm{CDCl}_{3}\right): \delta$ 3.18 (1H, m, H-3), 2.38 (1H, m, H-19), 0.95 (3H, s, H-23), 1.24 (3H, s, H-24), $0.98(3 \mathrm{H}, \mathrm{s}$, H-25), 1.01 (3H, s, H-26), 0.93 (3H, s, H-27), 0.81 (3H, s, H-28), 4.67 (1H, br.s, H-29a), 4.55 (1H, br.s, H-29b), 1.33 (3H, s, H-30). ${ }^{13} \mathrm{C}-\mathrm{NMR}$ $\left(125 \mathrm{MHz}, \mathrm{CDCl}_{3}\right): \delta 38.7(\mathrm{t}, \mathrm{C}-1), 27.5(\mathrm{t}, \mathrm{C}-$ 2), 79.0 (d, C-3), 38.9 (s, C-4), 55.1 (d, C-5), 18.4 (t, C-6), 34.3 (t, C-7), 40.8 (s, C-8), 50.4 (d, C-9), 37.2 (s, C-10), 20.9 (t, C-11), 25.1 (t, C-12), 38.1 (d, C-13), 42.9 (s, C-14), 27.4 (t, C15), 35.6 (t, C-16), 43.0 (s, C-17), 48.3 (d, C18), 48.0 (d, C-19), 151.0 (s, C-20), 29.9 (t, C21), 40.0 (t, C-22), 28.0 (q, C-23), 15.5 (q, C24), 16.2 (q, C-25), 16.0 (q, C-26), 14.5 (q, C- 
27), 18.1 (q, C-28), 109.4 (t, C-29), 19.4 (q, C30).

Compound (5): yellow amorphous powder. The UV/Vis. spectral data (Table 1). ${ }^{1} \mathrm{H}-\mathrm{NMR}$ $\left(400 \mathrm{MHz}, \mathrm{DMSO}-\mathrm{d}_{6}\right): \delta 6.71(1 \mathrm{H}, \mathrm{s}, \mathrm{H}-3)$, $6.19(1 \mathrm{H}, \mathrm{d}, J=2.6 \mathrm{~Hz}, \mathrm{H}-6), 6.47(1 \mathrm{H}, \mathrm{d}, J=$ $2.6 \mathrm{~Hz}, \mathrm{H}-8), 7.81\left(2 \mathrm{H}, \mathrm{d}, J=7.1 \mathrm{~Hz}, \mathrm{H}-22^{\prime}, 6\right)^{`}$, $6.87(2 \mathrm{H}, \mathrm{d}, J=7.1 \mathrm{~Hz}, \mathrm{H}-3,5) .{ }^{13} \mathrm{C}-\mathrm{NMR}$ (Table 2).

Compound (6): yellow amorphous powder. UV/Vis. spectral data (Table 1). ${ }^{1} \mathrm{H}-\mathrm{NMR}$ (400 MHz, DMSO-d $\mathrm{d}_{6}$ ): $\delta 6.21$ (1H, br.s, H-6), 6.42 (1H, br.s, H-8), $7.97(2 \mathrm{H}, \mathrm{d}, J=6.2 \mathrm{~Hz}, \mathrm{H}-2$, 6) $), 6.93(1 \mathrm{H}, \mathrm{d}, J=6.2 \mathrm{~Hz}, \mathrm{H}-3 `, 5), 12.68$ $(1 \mathrm{H}, \mathrm{s}, 5-\mathrm{OH}) .{ }^{13} \mathrm{C}-\mathrm{NMR}$ (Table 2).

Compound (8): white needles, m.p.: $122^{\circ} \mathrm{C}$. The ${ }^{1} \mathrm{H}-\mathrm{NMR}\left(500 \mathrm{MHz}, \mathrm{CDCl}_{3}\right): \delta 8.1(2 \mathrm{H}$, br.dd, $J=1.6,8.4 \mathrm{~Hz}, \mathrm{H}-2,6), 7.6(3 \mathrm{H}, \mathrm{m}, \mathrm{H}-3$, 4, 5). EI-MS $m / z: 122[\mathrm{M}]^{+}, 105[\mathrm{M}-\mathrm{OH}]^{+}$and $77[\mathrm{M}-\mathrm{COOH}]^{+}$.

Compound (9): yellow amorphous powder. UV/Vis. spectral data (Table 1). ${ }^{1} \mathrm{H}-\mathrm{NMR}$ (400 MHz, DMSO-d 6 ): $\delta 6.19(1 \mathrm{H}, \mathrm{d}, J=1.7 \mathrm{~Hz}, \mathrm{H}-$ 6), $6.42(1 \mathrm{H}, \mathrm{d}, J=1.7 \mathrm{~Hz}, \mathrm{H}-8), 8.02(2 \mathrm{H}, \mathrm{d}$, $\left.J=8.7 \mathrm{~Hz}, \mathrm{H}-2{ }^{\prime}, 6\right), 6.88(2 \mathrm{H}, \mathrm{d}, J=8.7 \mathrm{~Hz}, \mathrm{H}-$ 3`, 5), $5.42\left(1 \mathrm{H}, \mathrm{d}, J=7.3 \mathrm{~Hz}, \mathrm{H}-1^{\prime}\right), 3.10-$ $3.80\left(6 \mathrm{H}, \mathrm{m}, \mathrm{H}-2\right.$ " to H-6 $\left.{ }^{\prime}\right) .{ }^{13} \mathrm{C}-\mathrm{NMR}$ (Table $2)$.

Compound (10): colourless needles, m.p.: 195-197 ${ }^{\circ} \mathrm{C}$. ${ }^{1} \mathrm{H}-\mathrm{NMR}\left(400 \mathrm{MHz}, \mathrm{DMSO}-\mathrm{d}_{6}\right): \delta$ $6.72(2 \mathrm{H}, \mathrm{s}, \mathrm{H}-2,6), 6.56(1 \mathrm{H}, \mathrm{d}, J=15.7 \mathrm{~Hz}$, H-7), 6.35 (1H, dd, $J=15.7,5.8 \mathrm{~Hz}, \mathrm{H}-8), 4.21$ $(2 \mathrm{H}$, br.d, $J=5.8 \mathrm{~Hz}, \mathrm{H}-9), 4.85(1 \mathrm{H}, \mathrm{d}, J=7.7$ $\left.\mathrm{Hz}, \mathrm{H}-1^{\prime}\right), 3.50-3.85\left(6 \mathrm{H}, \mathrm{m}, \mathrm{H}-2^{\prime}\right.$ to $\left.\mathrm{H}-6^{\prime}\right)$, $3.77(6 \mathrm{H}, \mathrm{s}, 2-\mathrm{OMe}$ at $\mathrm{C}-3,5) .{ }^{13} \mathrm{C}-\mathrm{NMR}(100$ MHz, DMSO-d $\mathrm{d}_{6}$ ): $\delta 133.8$ (s, C-1), 104.4 (d, C2, 6), 152.6 (s, C-3, 5), 132.5 (s, C-4), 130.1 (d, C-7), 128.3 (d, C-8), 61.0 (t, C-9), 103.0 (d, C1'), 74.1 (d, C-2`), 77.5 (d, C-3`), 70.1 (d, C4), 77.0 (d, C-5) 61.4 (t, C-6 ) 56.5 (q, two $\mathrm{OMe})$.

Compound (11): yellow amorphous powder. UV/Vis. spectral data (Table 1). ${ }^{1} \mathrm{H}-\mathrm{NMR}$ (300 MHz, DMSO-d $\left.{ }_{6}\right): \delta 6.81(1 \mathrm{H}, \mathrm{s}, \mathrm{H}-3), 6.36$ $(1 \mathrm{H}, \mathrm{d}, J=1.9 \mathrm{~Hz}, \mathrm{H}-6), 6.78(1 \mathrm{H}, \mathrm{d}, J=1.9$ $\mathrm{Hz}, \mathrm{H}-8), 7.91\left(2 \mathrm{H}, \mathrm{d}, J=8.8 \mathrm{~Hz}, \mathrm{H}-22^{\prime}, 6^{`}\right)$, $6.87\left(2 \mathrm{H}, \mathrm{d}, J=8.8 \mathrm{~Hz}, \mathrm{H}-3^{`}, 5^{`}\right), 5.24(1 \mathrm{H}, \mathrm{d}$,
$J=7.3 \mathrm{~Hz}, \mathrm{H}-1^{\prime}$ '), 5.19 (1H, br.s, H-1 “'), 0.97 $\left(3 \mathrm{H}, \mathrm{d}, J=6.2 \mathrm{~Hz}, \mathrm{H}-6^{\cdots}\right), 3.20-3.95(10 \mathrm{H}, \mathrm{m}$, sugar protons). ${ }^{13} \mathrm{C}-\mathrm{NMR}$ (Table 2 ).

\section{Preparation of fatty acids ${ }^{7}$}

Five grams of the $n$-Hexane fraction was saponified by refluxing with $0.5 \mathrm{~N}$ ethanolic $\mathrm{KOH}$ for $3 \mathrm{hrs}$. The alcohol was distilled off and the aqueous liquid was diluted with water then extracted with ether till exhaustion. The combined ethereal extract was washed with water and the ether was distilled off under reduced pressure and dehydrated over anhydrous sodium sulphate. The alkaline aqueous solution that remained after removal of the unsaponifiable matter was acidified with dilute sulphuric acid and the liberated fatty acids were extracted with ether $(50 \mathrm{ml} \times 3)$. The combined ethereal extract was washed with distilled water to remove any acidity, and dried over anhydrous sodium sulphate. The solvent was distilled off under reduced pressure to give a viscous residue of the free fatty acids which has yellowish brown colour. A part of the residue was subjected to methylation as follow $^{8 \& 9}$ :

About one gram of the fatty acids was esterified by mixing with anhydrous $\mathrm{K}_{2} \mathrm{CO}_{3}$ (2 g) and $\left(\mathrm{CH}_{3}\right)_{2} \mathrm{SO}_{4}(5 \mathrm{ml})$ in dry acetone and refluxed on water bath for 4 hrs. After filtration, the filtrate was concentrated to remove acetone, diluted with water and extracted with ethyl acetate. The ethyl acetate layer was washed with water, dried over anhydrous sodium sulphate and concentrated to yield an oily residue, dissolved in methanol and analyzed by GC.

\section{Gas-liquid chromatography (GLC) of the fatty acid methyl esters}

GLC analysis of the fatty acid methyl esters was performed using JEOL GC mate Ionization Mode 0020. Gas chromatograph equipped with flame ionization detector and fitted with 3\% OV-17 on Carbowax HP 80/100 (6 x $\left.1 / 8^{\prime \prime} \times 0.085^{\prime}\right)$ SS column, programmed at $160^{\circ} \mathrm{C}$ for $2 \mathrm{~min}$ then increase by $15^{\circ} \mathrm{C} / \mathrm{min}$ till $300^{\circ} \mathrm{C}$ and isothermal for $15 \mathrm{~min}$ Injector and detector temperature were $250^{\circ} \mathrm{C}$ and $320^{\circ} \mathrm{C}$ respectively.

\section{Biological study}


The biological studies were performed on the different fractions: $n$-hexane, chloroform, ethyl acetate, $n$-butanol, total methanolic and aqueous extracts.

Preparation of the extract for of the $\mathrm{LD}_{50}$ determination: weighed amounts of $n$-hexane, chloroform, ethyl acetate, $n$-butanol and total methanolic extract were dissolved in distilled water with the aid of $2 \%$ Tween 80. Subsequent dilutions were made in normal saline. Control solution was made using $2 \%$ of Tween 80 as a negative control.

\section{Preparation of the extracts for pharmacological study: the $n$-hexane, chloroform, ethyl acetate, $n$-butanol and total methanolic extract were separately taken in weighed amounts and solublized in normal saline with the aid of $2 \%$ Tween 80 . Aqueous extract $(100 \mathrm{mg} / \mathrm{kg})$ was also used.}

Experimental animals: male albino rats (100$120 \mathrm{~g})$ and mice (20-25 g) were used. They were fed with standard diet and free access to water and housed under standardized environmental conditions in the preclinical animal house, Pharmacology Department, Faculty of Medicine, Assiut University.

\section{Statistical Analysis}

All the results were expressed as mean \pm standard error of the mean. The significance in results from control group was calculated using the student's $\mathrm{t}$-test ${ }^{10} .{ }^{*} \mathrm{P}<0.05$ or less considered as positive result.

\section{Materials for biological study}

Normal saline $0.9 \%$ [El-Nasr Pharmaceutical and Chemical Co., Egypt.] (ADWIC). Indomethacin as antipyretic and anti-inflammatory drug (El-Nile Co., Egypt). Carrgeenan as a factor inducing edema. Yeast as a factor inducing pyrexia. Pentylenetetrazol as a factor inducing convulsions and death (Sigma Chemical Co., St. Louis, USA). Carbamazepine as a standard anti-convulsant agent (Novarts Co., Switzerland). Carbon tetrachloride $\left(\mathrm{CCl}_{4}\right)$ to induce liver damage.

\section{(a) Determination of the $\mathrm{LD}_{50}$}

Mice were divided into several groups (6 mice, each). The tested fractions were i.p. injected and continuously observed for $2 \mathrm{hrs}$ to detect any changes in the autonomic or behavioral responses and then monitored for any mortality. A group of mice was treated with the vehicle ( $2 \%$ Tween 80$)$ as control group. The $\mathrm{LD}_{50}$ was determined according to the reported method ${ }^{11}$.

\section{(b) Preliminary pharmacological study}

The different fractions, total methanolic and aqueous extracts of Eranthemum nervosum were screened for their effects on inflammation, hyperpyrexia, motor coordination, convulsion and hepatoprotective activity.

\section{1- Anti-inflammatory activity}

The method described by Winter et al. ${ }^{12}$ was used. Seven groups each of five male albino rats were used. The pedal inflammation was induced in rat paws by injection of $0.1 \mathrm{ml}$, $1 \%$ carrageenan suspension in $0.9 \% \mathrm{NaCl}$ solution into the subplantar tissue of the right hind paw. At the beginning of the experiment, the paws thickness was measured in mm using Varnier Caliper. The first group was kept as negative control injected i.p. by $2 \%$ Tween 80 in normal saline; the second group was injected by indomethacin (reference group, $8 \mathrm{mg} / \mathrm{kg}$ ). The other groups were separately injected i.p. with the different fractions $(200 \mathrm{mg} / \mathrm{kg})$. After 30 minutes, the inflammation was induced by injection of the carrageenan suspension in the right hind paw while the left one was injected by an equal volume of saline solution. The increase in linear paw circumference was taken as a measure of edema ${ }^{13}$. The antiinflammatory efficacy of the tested fractions was estimated by comparing the magnitude of paw swelling in the pretreated animals with those induced in control animals receiving saline. The measurement was carried out at 1 , 2, 3 and 4 hrs after injection of the inflammatory agent. The percentage of inhibition were calculated as follows: $\left(\mathrm{V}_{0}-\mathrm{V}_{\mathrm{t}}\right)$ $\mathrm{x} 100 / \mathrm{V}_{0}$, where: $\mathrm{V}_{0}$ : the average paw thickness of control group and $\mathrm{V}_{\mathrm{t}}$ : the average paw thickness of the treated group. 


\section{2- Antipyretic activity}

Seven groups (5 rats, each) were used. Hyperthermia was induced by subcutaneous injection of $20 \%$ (w/v) aqueous suspension of yeast in a volume of $10 \mathrm{ml} / \mathrm{kg}$. The first group was kept as negative control injected i.p. by $2 \%$ Tween 80 in normal saline, while the second group injected by indomethacin $(8 \mathrm{mg} / \mathrm{kg})$. The other groups were separately injected i.p with the different fractions $(200 \mathrm{mg} / \mathrm{kg})$. Rectal temperatures were taken at $0,1,2$ and $3 \mathrm{hrs}$ after administration of tested fractions ${ }^{14}$ using a thermometer.

\section{3- Activity on the central nervous system}

The activity on the central nervous system were evaluated by performing assays of their effects on:

a- Motor co-ordination (Rota-rod test)

b- Pentylenetetrazol induced convulsion

\section{a- Assay of the effects on motor co- ordination (Rota-rod test)}

Boissier's method ${ }^{15 \& 16}$ was used where mice were placed on a Rota-rod and those staying on the rod for more than three minutes were selected for the experiment. Six groups (5 mice, each) were placed on the rod 30 and 60 minutes after i.p. injection of the control or test fractions with a dose $(200 \mathrm{mg} / \mathrm{kg})$. The time they stayed on the rod was recorded.

\section{b- Effect on pentylenetetrazol induced convulsion}

Seven groups (5 mice, each) were used. The control group was injected i.p with PTZ $(100 \mathrm{mg} / \mathrm{kg}$ ) alone. The second group was i.p. injected with PTZ after 30 minutes from i.p. injection of $5 \mathrm{mg} / \mathrm{kg}$ carbamazepine as anticonvulsant drug. Other groups were i.p. injected with the tested fractions $(200 \mathrm{mg} / \mathrm{kg})$ 30 minutes before the i.p. injection of PTZ. Latencies to the onset of clonic, tonic and the mortality were evaluated during $30 \mathrm{~min}$ after PTZ injection ${ }^{17}$.

\section{4- Hepatoprotective activity $\mathrm{CCl}_{4}$-induced hepatotoxicity}

Carbon tetrachloride $\left(\mathrm{CCl}_{4}\right)$ is a widely used chemical in experimental studies to induce liver damage which is reflected by an increase in the levels of hepatospecific enzymes; these are cytoplasmic and are released into circulation after cellular damage $^{18}$. The increase in the total bilirubin content, GOT (glutamate oxaloacetate transaminase) and GPT (glutamate pyruvate transaminase) in the $\mathrm{CCl}_{4}$ treated group could be taken as an index of liver damage and by centrilobular necrosis ${ }^{19-21}$. For inducing hepatotoxicity, four groups (5 rats, each) were injected i.p. with $\mathrm{CCl}_{4}$ in olive oil $(1: 1 \mathrm{v} / \mathrm{v})$ at a dose of $0.7 \mathrm{ml} / \mathrm{kg}$ of body weight for 7 days. The aqueous extract of the plant was forcefully fed (by feeding needle) at a dose of $100 \mathrm{mg} / \mathrm{kg}$ of body weight during $\mathrm{CCl}_{4}$ intoxication and continued for 15 days. After completing the treatment, blood was collected from the retroorbital plexus of respective animals. The blood samples after coagulation were centrifuged and the sera isolated were used for estimation of the biochemical markers of liver damage viz. GOT, GPT, total lipid and total bilirubin levels.

\section{RESULTS AND DISCUSSION}

All compounds were isolated from the methanolic extract of the air-dried aerial parts of Eranthemum nervosum. Compounds 1-4 and 7 gave positive colour reactions for sterols and/ or triterpenes ${ }^{22 \& 23}$, while compounds 5, 6,9 and $\mathbf{1 1}$ gave positive tests for flavonoids ${ }^{24}$.

The identification of compounds $1,2,4$ and $\mathbf{7}$ as $\beta$-amyrin, $\alpha$-amyrin, $\beta$-sitosterol and $\beta$ sitosterol glucoside respectively were established through different physical, chemical and spectral data together with cochromatography with authentic samples and to the best of our knowledge these compounds were isolated here for the first time from the genus Eranthemum.

Compound 3: The ${ }^{13} \mathrm{C}$-NMR showed 30 signals corresponding to 30 carbon atoms including 7 methyl, 11 methylene, 6 methine groups including one oxymethine and 6 quaternary atoms. The chemical shifts suggest the presence of triterpenoid skeleton ${ }^{25}$. The carbon resonances at $\delta_{\mathrm{C}} 151.0(\mathrm{~s}, 1 \mathrm{C})$ and $\delta_{\mathrm{C}}$ $109.4\left(\mathrm{t}, 1 \mathrm{C}\right.$ ) with $\delta_{\mathrm{H}} 4.67,4.55$ (each $1 \mathrm{H}$, br.s) indicated the presence of terminal methylene moiety $^{26}$. The chemical shifts of methine groups including the oxymethine group at $\delta_{\mathrm{C}} 79$ with $\delta_{\mathrm{H}} 3.18(1 \mathrm{H}, \mathrm{m})$ in addition to other signals for methyls at $\delta_{\mathrm{C}} 28.0$ with $\delta_{\mathrm{H}} 0.95 ; \delta_{\mathrm{C}}$ 15.5 with $\delta_{\mathrm{H}} 1.24 ; \delta_{\mathrm{C}} 16.2$ with $\delta_{\mathrm{H}} 0.98 ; \delta_{\mathrm{C}} 16.0$ 
with $\delta_{\mathrm{H}} 1.01 ; \delta_{\mathrm{C}} 14.5$ with $\delta_{\mathrm{H}} 0.93 ; \delta_{\mathrm{C}} 18.1$ with $\delta_{\mathrm{H}} 0.81$ and $\delta_{\mathrm{C}} 19.4$ with $\delta_{\mathrm{H}} 1.33$ and methylene cluster in the ${ }^{1} \mathrm{H}-\mathrm{NMR}$ confirmed the triterpenoid nature of the compound. Comparing the spectral data with that reported for triterpenoids indicated the presence of lupeol ${ }^{25 \& 26}$. The $\beta$-configuration of $\mathrm{OH}$ group at $\mathrm{C}-3$ was deduced from the ${ }^{13} \mathrm{C}-\mathrm{NMR}$ and comparing the data with that reported for related compounds ${ }^{25}$. Lupeol is isolated here for the first time from the genus Eranthemum.

Compound 5: Different colour reactions ${ }^{24 \& 27}$ and the ${ }^{13} \mathrm{C}-\mathrm{NMR}$ spectral data (Table 2) of the compound showed 15 carbon atoms indicating a flavonoid skeleton ${ }^{28 \& 29}$. The UV/Vis. spectrum confirmed the flavonoid skeleton from the two characteristic bands (band I at 338 and II at $268 \mathrm{~nm}$ ) most probably of flavone nucleus $^{27}$. The UV/Vis. data with different ionizing and complexing reagents (Table 1) showed the presence of free $\mathrm{OH}$ group at $\mathrm{C}-4$ from the bathochromic shift $(+52)$ in band I after addition of $\mathrm{NaOMe}$ comparing with $\mathrm{MeOH}$; presence of free $\mathrm{OH}$ group at C-7 from the bathochromic shift $(+8)$ of band II after addition of $\mathrm{NaOAc}$; presence of free $\mathrm{OH}$ at $\mathrm{C}-5$ and absence of ortho-dihydroxy group from the bathochromic shift in band I (+46) after addition of $\mathrm{AlCl}_{3}$ and the stability of the formed complex after addition of $\mathrm{HCl}$ and confirmed from the absence of bathchromic shift in band I after addition of $\mathrm{NaOAc} / \mathrm{H}_{3} \mathrm{BO}_{3}$. The ${ }^{1}$ H-NMR spectral data showed a characteristic pattern for a flavone ${ }^{27}$, represented by two doublets at $\delta_{\mathrm{H}} 6.47$ and 6.19 (each $1 \mathrm{H}, J=2.6 \mathrm{~Hz}$ ) for meta-coupling protons assigned for $\mathrm{H}-8$ and $\mathrm{H}-6$ respectively. In addition, a typical $\mathrm{A}_{2} \mathrm{~B}_{2}$ pattern represented by two sets of ortho-coupled aromatic protons at $\delta_{\mathrm{H}} 7.81$ and 6.87 (each $2 \mathrm{H}, \mathrm{d}, J=7.1 \mathrm{~Hz}$ ) assigned to $\mathrm{H}-2$, 6 and $\mathrm{H}-3$, 5 respectively. Furthermore, a singlet proton at $\delta_{\mathrm{H}} 6.71$ was assigned for $\mathrm{H}-3$. The above data were found to be identical with those reported for apigenin ${ }^{27-}$ ${ }^{30}$, and reported here for the first time from the genus Eranthemum.

Compound 6: The UV data of the compound (Table 1) showed a typical flavonol structure ${ }^{24 \& 27}$ with free hydroxyl groups at C4, C-7 and C-5 and lacking of ortho-dihydroxy groups in both rings from the bathochromic shifts after addition of $\mathrm{NaOMe}$ for $\mathrm{C}-4$, $\mathrm{NaOAc}$ for $\mathrm{C}-7, \mathrm{AlCl}_{3} / \mathrm{HCl}$ for $\mathrm{C}-5$ and $\mathrm{NaOAc} / \mathrm{H}_{3} \mathrm{BO}_{3}$ for ortho-dihydroxy groups. The ${ }^{1}$ H-NMR showed typical flavonol structure, noted from the absence of a singlet proton signal characteristic for $\mathrm{H}-3$ of flavone nucleus $^{27}$. The spectral data as in compound $\mathbf{5}$ showed an $\mathrm{A}_{2} \mathrm{~B}_{2}$ pattern from the two doublet signals at $\delta_{\mathrm{H}} 7.97$ and $\delta_{\mathrm{H}} 6.93$ (each $2 \mathrm{H}, J=6.2$ $\mathrm{Hz}$ ) assigned for $\mathrm{H}-2{ }^{\prime}, 6^{\prime}$ and $\mathrm{H}-3{ }^{\prime}, 5^{\prime}$ respectively, indicating a para-disubstituted ring; two broad singlet signals at $\delta_{\mathrm{H}} 6.21$ and 6.42 (each $1 \mathrm{H}$ ) assigned to $\mathrm{H}-6$ and $\mathrm{H}-8$ respectively. In addition; a downfield signal at $\delta_{\mathrm{H}} 12.6842(1 \mathrm{H}$, br.s $)$ was assigned for $5-\mathrm{OH}$. The ${ }^{13} \mathrm{C}$-NMR data (Table 2) confirmed the flavonol structure from the presence of 13 signals representing 15 carbon atoms nearly similar to those of $\mathbf{5}$ with the exception of a carbon doublet at $\delta_{\mathrm{C}} 102.6$ for compound $\mathbf{5}$ and a singlet at $\delta_{\mathrm{C}} 134.7$ for compound $\mathbf{6}$ which affect the chemical shifts of C-2 and C- $4{ }^{22 \& 28}$. These chemical shifts were found to be in good agreement with those reported for kaempferol ${ }^{28}$ that reported here for the first time in the genus Eranthemum.

Compound 8: The ${ }^{1} \mathrm{H}-\mathrm{NMR}$ data of compound 8 showed aromatic signals at $\delta 8.13(2 \mathrm{H}$, br.dd, $J=1.6,8.4 \mathrm{~Hz}, \mathrm{H}-2,6), 7.62$ (3H, m, H-3, 4, 5) attributed for monosubstituted benzene ring. The EI-MS which gave $\mathrm{M}^{+}$at $\mathrm{m} / \mathrm{z} 122$ and fragments at $105[\mathrm{M}-\mathrm{OH}]$ and at $77[\mathrm{M}-\mathrm{COOH}]$ are characteristic for benzoic acid ${ }^{31}$. These data and co-chromatography with authentic sample indicated that compound $\mathbf{8}$ is benzoic acid and this is the first report about its isolation from the genus Eranthemum.

Compound 9: The positive test for carbohydrate indicated its glycosidic nature while the ${ }^{13} \mathrm{C}$-NMR indicated its flavonoid skeleton. UV/Vis. data (Table 1) confirmed the flavonoid structure ${ }^{27}$ and showed the presence of free $\mathrm{OH}$ groups at C-4, C-5 and C-7 as in compound 5. The ${ }^{1} \mathrm{H}-\mathrm{NMR}$ data were similar to that of compound 7 in addition to signals for the sugar moiety at $\delta_{\mathrm{H}} 5.42(1 \mathrm{H}, \mathrm{d}, J=7.3 \mathrm{~Hz})$ for the anomeric proton $\mathrm{H}-1$ " and 3.10-3.80 for the remaining protons. The acid hydrolysis was carried out giving the sugar which was identified as glucose and the aglycone as 


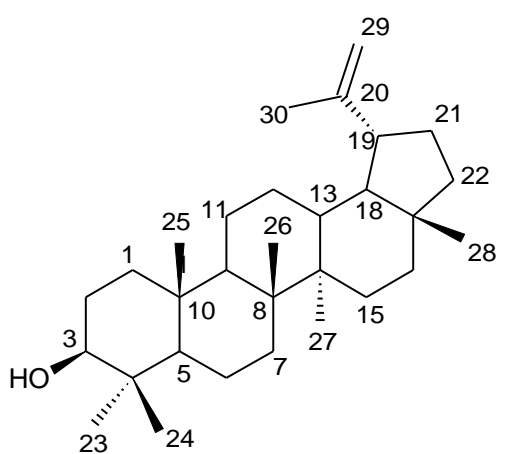

3<smiles>O=C(O)c1ccccc1</smiles>

8<smiles></smiles>

$5 \quad 6 \quad 9$

11

$\begin{array}{lllll}\mathbf{R} & \mathbf{H} & \mathbf{H} & \mathbf{H} & \text { neohesperidoside }\end{array}$

$\begin{array}{lllll}\mathbf{R}_{1} & \mathrm{H} & \mathrm{OH} & \text { O-glucose } & \text { H }\end{array}$<smiles>COc1cc(/C=C/CO)cc(OC)c1OC(Cl)(Cl)OCl</smiles>

10

The structures of the isolated compounds

Table 1: UV spectral data of compounds 5, 6, 9 and 11 with different ionizing and complexing reagents.

\begin{tabular}{|c|c|c|c|c|c|c|c|c|c|c|c|c|}
\hline \multirow{3}{*}{$\begin{array}{c}\text { Cpd. } \\
\text { No. }\end{array}$} & \multirow{3}{*}{ Bands } & \multicolumn{11}{|c|}{$\lambda_{\max }$ and $\Delta \lambda_{\max } \mathrm{nm}$} \\
\hline & & \multirow{2}{*}{$\frac{\mathrm{MeOH}}{\lambda_{\max }}$} & \multicolumn{2}{|c|}{$\mathrm{NaOMe}$} & \multicolumn{2}{|c|}{$\mathrm{NaOAc}$} & \multicolumn{2}{|c|}{$\mathrm{NaOAc} / \mathrm{H}_{3} \mathrm{BO}_{3}$} & \multicolumn{2}{|c|}{$\mathrm{AlCl}_{3}$} & \multicolumn{2}{|c|}{$\mathrm{AlCl}_{3} / \mathrm{HCl}$} \\
\hline & & & $\lambda_{\max }$ & $\Delta \lambda$ & $\lambda_{\max }$ & $\Delta \lambda$ & $\lambda_{\max }$ & $\Delta \lambda$ & $\lambda_{\max }$ & $\Delta \lambda$ & $\lambda_{\max }$ & $\Delta \lambda$ \\
\hline \multirow{2}{*}{5} & I & 338 & 390 & +52 & 375 & +37 & 340 & +2 & 384 & +46 & 384 & +46 \\
\hline & II & 268 & 274 & +6 & 276 & +8 & 269 & +1 & 278 & +10 & 278 & +10 \\
\hline \multirow{2}{*}{6} & I & 374 & 442 & +68 & 378 & +4 & 377 & +5 & 434 & +60 & 434 & +60 \\
\hline & II & 270 & 288 & +18 & 276 & +6 & 270 & - & 276 & +6 & 274 & +4 \\
\hline \multirow{2}{*}{9} & I & 356 & 410 & +54 & 373 & +20 & 356 & - & 402 & +46 & 402 & +46 \\
\hline & II & 272 & 280 & +8 & 280 & +8 & 272 & - & 278 & +6 & 279 & +7 \\
\hline \multirow{2}{*}{11} & I & 339 & 386 & +47 & 386 & +47 & 341 & +2 & 388 & +49 & 386 & +47 \\
\hline & II & 269 & 274 & +5 & 269 & - & 269 & - & 275 & +6 & 277 & +8 \\
\hline
\end{tabular}


Table 2: ${ }^{13} \mathrm{C}-\mathrm{NMR}$ spectral data of compounds 5, 6,9 and 11 in DMSO-d $\mathrm{d}_{6}$.

\begin{tabular}{|c|c|c|c|c|}
\hline $\mathrm{C}$ & 5 & 6 & 9 & 11 \\
\hline 2 & $163.6(\mathrm{~s})$ & $145.9(\mathrm{~s})$ & $156.7(\mathrm{~s})$ & $164.1(\mathrm{~s})$ \\
\hline 3 & $102.6(\mathrm{~d})$ & $134.7(\mathrm{~s})$ & $133.5(\mathrm{~s})$ & $103.5(\mathrm{~d})$ \\
\hline 4 & $181.3(\mathrm{~s})$ & $175.0(\mathrm{~s})$ & $177.7(\mathrm{~s})$ & $182.0(\mathrm{~s})$ \\
\hline 5 & $161.2(\mathrm{~s})$ & $160.2(\mathrm{~s})$ & $161.5(\mathrm{~s})$ & $161.0(\mathrm{~s})$ \\
\hline 6 & $99.6(\mathrm{~d})$ & $97.3(\mathrm{~d})$ & $99.0(\mathrm{~d})$ & $98.0(\mathrm{~d})$ \\
\hline 7 & $163.6(\mathrm{~s})$ & $162.8(\mathrm{~s})$ & $164.4(\mathrm{~s})$ & $162.5(\mathrm{~s})$ \\
\hline 8 & $94.2(\mathrm{~d})$ & $92.4(\mathrm{~d})$ & $94.0(\mathrm{~d})$ & $94.6(\mathrm{~d})$ \\
\hline 9 & $157.3(\mathrm{~s})$ & $154.8(\mathrm{~s})$ & $156.7(\mathrm{~s})$ & $157.3(\mathrm{~s})$ \\
\hline 10 & $103.5(\mathrm{~s})$ & $102.3(\mathrm{~s})$ & $104.3(\mathrm{~s})$ & $105.4(\mathrm{~s})$ \\
\hline 1 & $121.3(\mathrm{~s})$ & $121.1(\mathrm{~s})$ & $121.2(\mathrm{~s})$ & $121.3(\mathrm{~s})$ \\
\hline 2 & $128.4(\mathrm{~d})$ & $128.6(\mathrm{~d})$ & $131.2(\mathrm{~d})$ & $128.5(\mathrm{~d})$ \\
\hline 3 & $116.2(\mathrm{~d})$ & $114.6(\mathrm{~d})$ & $115.4(\mathrm{~d})$ & $116.0(\mathrm{~d})$ \\
\hline 4 & $161.0(\mathrm{~s})$ & $158.1(\mathrm{~s})$ & $160.2(\mathrm{~s})$ & $156.9(\mathrm{~s})$ \\
\hline 5 & $116.2(\mathrm{~d})$ & $114.6(\mathrm{~d})$ & $115.4(\mathrm{~d})$ & $116.0(\mathrm{~d})$ \\
\hline 6 & $128.4(\mathrm{~s})$ & $128.6(\mathrm{~d})$ & $131.2(\mathrm{~d})$ & $128.5(\mathrm{~d})$ \\
\hline $1 "$ & & & $101.2(\mathrm{~d})$ & $99.3(\mathrm{~d})$ \\
\hline $2 "$ & & & $74.5(\mathrm{~d})$ & $77.1(\mathrm{~d})$ \\
\hline $3 "$ & & & $76.6^{\mathrm{a}}(\mathrm{d})$ & $76.3(\mathrm{~d})$ \\
\hline 4 & & & $70.1(\mathrm{~d})$ & $69.7(d)$ \\
\hline $5^{\prime \prime}$ & & & $77.6^{\mathrm{a}}(\mathrm{d})$ & $77.2(\mathrm{~d})$ \\
\hline 6 & & & $61.0(\mathrm{t})$ & $60.5(\mathrm{t})$ \\
\hline $1{ }^{\prime \prime}$ & & & & $100.4(\mathrm{~d})$ \\
\hline $2 \cdots$ & & & & $70.3^{\mathrm{a}}(\mathrm{d})$ \\
\hline $33^{\prime \prime}$ & & & & $70.4^{\mathrm{a}}(\mathrm{d})$ \\
\hline 4 "' & & & & $71.8(\mathrm{~d})$ \\
\hline 5 "' & & & & $68.3(\mathrm{~d})$ \\
\hline $6 "$ & & & & $18.0(\mathrm{q})$ \\
\hline
\end{tabular}

${ }^{a}$ data in each column may be interchangeable.

kaempferol by paper chromatography and TLC alongside authentic samples. The $\beta$ configuration of glucose was determined from the large coupling constant of the anomeric proton $(7.3 \mathrm{~Hz})$ and it's attachement to C-3 by comparing the UV colour of the spots on the TLC before and after hydrolysis; the upfield shift of C-3 (-1.2 ppm), downfield shift of C-4 $(+2.7 \mathrm{ppm})$ and pronounced downfield shift of C-2 (+10.8 $\quad$ ppm $) \quad$ comparing with kaempferol $^{28 \& 29}$. From the above-mentioned data, compound 9 was identified as kaempferol-3-O- $\beta$-D-glucopyranoside which is isolated here for the first time from the genus Eranthemum.

Compound 10: The ${ }^{1} \mathrm{H}-\mathrm{NMR}$ data of compound $\mathbf{1 0}$ showed the presence of a singlet aromatic signal at $\delta_{\mathrm{H}} 6.72(2 \mathrm{H})$ which in addition to six signals at $\delta_{\mathrm{C}} 132.5(\mathrm{~s}, 1 \mathrm{C}), 152.6$ (s, 2C), $104.4(\mathrm{~d}, 2 \mathrm{C}), 133.8$ (s, 1C), in the ${ }^{13} \mathrm{C}$ NMR data suggested the presence of tetrasubstituted benzene ring. These data with the signals at $\delta_{\mathrm{H}} 6.56(1 \mathrm{H}, \mathrm{d}, J=15.7 \mathrm{~Hz})$ with $\delta_{\mathrm{C}} 130.1(\mathrm{~d}, 1 \mathrm{C}) ; \delta_{\mathrm{H}} 6.35(1 \mathrm{H}, \mathrm{dd}, J=15.7,5.8$ $\mathrm{Hz})$ with $\delta_{\mathrm{C}} 128.3(\mathrm{~d}, 1 \mathrm{C})$ and $\delta_{\mathrm{H}} 4.21(2 \mathrm{H}$, br.d, $J=5.8 \mathrm{~Hz})$ with $\delta_{\mathrm{C}} 61.0(\mathrm{t}, 1 \mathrm{C})$, indicated the presence of tetrasubstituted trans cinnamoyl alcohol moiety. A signal at $\delta_{\mathrm{H}} 3.77$ $(6 \mathrm{H}, \mathrm{s})$ with $\delta_{\mathrm{C}} 56.5(\mathrm{q}, 2 \mathrm{C})$ indicated the presence of two aromatic methoxy groups. Other NMR data showed signals at $\delta_{\mathrm{C}} 103.0(\mathrm{~d}$, $1 \mathrm{C})$ with $\delta_{\mathrm{H}} 4.85(1 \mathrm{H}, \mathrm{d}, J=7.7 \mathrm{~Hz})$ and five carbon signals at $\delta_{\mathrm{C}} 74.1,77.5,70.1,77.0$ (each d) and $61.4(\mathrm{t})$ with $\delta_{\mathrm{H}} 3.50-3.85(6 \mathrm{H}, \mathrm{m})$ which indicated the presence of glucose as a sugar 
moiety in $\beta$-configuration. The attachment of the two methoxy groups to the aromatic ring was deduced from their chemical shift values and by comparison with related compounds (syringinoside, solargin I, II, III and IV) ${ }^{32 \& 33}$, while the attachment of glucose moiety to C-4 not to C-9 was deduced from the chemical shift of C-9 $\left(\delta_{\mathrm{C}} 61.0\right)$ and also from the reported data $^{32-36}$. The above-mentioned data proved that compound $\mathbf{1 0}$ is Syringin ${ }^{36}$ which is isolated here for the first time from the genus Eranthemum.

Compound 11: different colour reactions and spectral analysis of compound $\mathbf{1 1}$ indicated it's flavonoid glycoside nature ${ }^{24,27-29}$. The ${ }^{13} \mathrm{C}-\mathrm{NMR}$ showed 25 signals equivalent to 27 carbon atoms, 13 of them are equivalent to 15 carbon atoms with their ${ }^{1} \mathrm{H}-\mathrm{NMR}$ data indicated the presence of flavone nucleus while the other 12 signals for a sugar moiety. The UV/Vis. data (Table 1) showed typical flavone structure with free $\mathrm{OH}$ groups at $\mathrm{C}-4$ and $\mathrm{C}-5$ and absence of orthodihydroxy groups as in compound $\mathbf{5}$. The absence of free $\mathrm{OH}$ group or blocked C-7 position was established from the absence of bathochromic shift in band II after addition of NaOAc. ${ }^{1} \mathrm{H}$ and ${ }^{13} \mathrm{C}$-NMR spectra showed two protons at $\delta_{\mathrm{H}} 5.24(1 \mathrm{H}, \mathrm{d}, J=7.3 \mathrm{~Hz})$ with $\delta_{\mathrm{C}}$ 99.3 and $\delta_{\mathrm{H}} 5.19(1 \mathrm{H}$, br.s $)$ with $\delta_{\mathrm{C}} 100.4$, in addition to a doublet at $\delta_{\mathrm{H}} 0.97(3 \mathrm{H}, \mathrm{d}, J=6.2$ $\mathrm{Hz})$ with $\delta_{\mathrm{C}} 18.0$ indicating the presence of two sugars most probably glucose and rhamnose in $\beta$ - and $\alpha$ - configuration respectively. C-1" of rhamnose was found to be attached to $\mathrm{C}-2$ of glucose from the downfield shift of C-2" $\left(\delta_{\mathrm{C}}\right.$ 77.1) $)^{37}$.

Acid hydrolysis yielded glucose and rhamnose (confirmed by PC) as a sugar moiety and apigenin aglycone (co-chromatography with authentic sample and similarity of its UV/Vis. data with that of 5). The above data were found to be identical with those reported for Apigenin 7-O-neohesperidoside ${ }^{27,29 \& 38}$ and this represents the first isolation of $\mathbf{1 1}$ from the genus Eranthemum.

\section{Biological study}

- The $\mathrm{LD}_{50}$ results (Table 3) revealed that the different extracts of the aerial parts of $E$. nervosum are safe enough to be used and the ethyl acetate is the safest fraction.

- Different fractions as well as total methanolic extract showed anti-inflammatory activity which reduced the carrageenaninduced edema with maximum effects being obtained after 3 hrs. (Table 4) and wellmarked antipyretic activity (Table 5). They reduce yeast-induced fever compared with indomethacin $(8 \mathrm{mg} / \mathrm{kg})$ with maximum activity after $2 \mathrm{hrs}$. The best fractions were the $n$-hexane, ethyl acetate and $n$-butanol.

- All fractions attained a central nervous system depressant activity (Table 6). The total methanolic extract has potent anticonvulsant activity against PTZ induced convulsion comparable to that of carbamazepine while the $n$-hexane fraction (200 mg/kg) has a mild effect. Other fractions have no effect (Table 7).

- Pretreatment of the rats with aqueous extract of the plant inhibited the increase in levels of GPT, GOT, total lipids and total bilirubin (Table 8). This suggests the maintenance of structural integrity of hepatocytic cell membrane or regeneration of damaged liver cells by the extract. The decrease in serum bilirubin after treatment with the extract in liver damage indicates the effectiveness of the extract in normal functional status of the liver. Thus, it is evident that the total aqueous extract has remarkable hepatoprotective effect in $\mathrm{CCl}_{4}$-induced liver damage.

\section{Fatty acids analysis}

The fatty acids analysis showed the presence of saturated acids (lauric, myristic, palmetic, stearic, behenic and cerotic acid); unsaturated acids (palmetoleic, oleic, linoleic, linolenic and erucic acids). The major acids were palmetic, linoleic and oleic (Table 9).

Table 3: The $\mathrm{LD}_{50}$ of different fractions and the total methanolic extract of the aerial parts.

\begin{tabular}{|c|c|c|c|c|c|}
\hline Extract & $\begin{array}{c}\text { total methanolic } \\
\text { extract }\end{array}$ & $\begin{array}{c}n \text {-hexane } \\
\text { fraction }\end{array}$ & $\begin{array}{c}\text { chloroform } \\
\text { fraction }\end{array}$ & $\begin{array}{c}\text { EtOAc } \\
\text { fraction }\end{array}$ & $\begin{array}{c}n \text {-butanol } \\
\text { fraction }\end{array}$ \\
\hline $\mathrm{LD}_{50}(\mathrm{~g} / \mathrm{Kg})$ & 0.9 & 3 & 3 & 3.5 & 2.5 \\
\hline
\end{tabular}


Table 4: Results of the anti-inflammatory activity and inhibitory effects of the different fractions on Carrageenan induced edema in rats.

\begin{tabular}{|l|c|c|c|c|c||}
\hline \multirow{2}{*}{ Group } & \multirow{2}{*}{$\begin{array}{c}\text { Dose } \\
\mathrm{mg} / \mathrm{Kg}\end{array}$} & \multicolumn{5}{|c|}{ Thickness of the right paw (mm) after injection (Mean \pm S.E), $\mathrm{n}=5$} \\
\cline { 3 - 6 } & & $1 \mathrm{hr}$ & $2 \mathrm{hrs}$ & $3 \mathrm{hrs}$ & $4 \mathrm{hrs}$ \\
\hline Control & --- & $\begin{array}{c}8.77 \pm 0.15 \\
(-)\end{array}$ & $\begin{array}{c}8.91 \pm 0.14 \\
(-)\end{array}$ & $\begin{array}{c}9.16 \pm 0.21 \\
(-)\end{array}$ & $\begin{array}{c}8.95 \pm 0.27 \\
(-)\end{array}$ \\
\hline Indomethacin & 8 & $\begin{array}{c}7.22 \pm 0.19^{* *} \\
(17.64)\end{array}$ & $\begin{array}{c}7.41 \pm 0.17^{* *} \\
(16.79)\end{array}$ & $\begin{array}{c}7.43 \pm 0.18^{* *} \\
(18.89)\end{array}$ & $\begin{array}{c}7.36 \pm 0.94^{* *} \\
(17.85)\end{array}$ \\
\hline Total extract & 200 & $\begin{array}{c}7.71 \pm 0.18 \\
(12.09)\end{array}$ & $\begin{array}{c}7.31 \pm 0.27^{*} \\
(17.97)\end{array}$ & $\begin{array}{c}7.44 \pm 0.16^{* * *} \\
(18.86)\end{array}$ & $\begin{array}{c}7.85 \pm 0.19 \\
(12.32)\end{array}$ \\
\hline $\begin{array}{l}n \text {-Hexane } \\
\text { fraction }\end{array}$ & 200 & $\begin{array}{c}7.30 \pm 0.24 \\
(16.77)\end{array}$ & $\begin{array}{c}7.05 \pm 0.31^{* *} \\
(20.79)\end{array}$ & $\begin{array}{c}7.47 \pm 0.18^{* *} \\
(18.45)\end{array}$ & $\begin{array}{c}7.51 \pm 0.18^{* *} \\
(16.14)\end{array}$ \\
\hline $\begin{array}{l}\text { Chloroform } \\
\text { fraction }\end{array}$ & 200 & $\begin{array}{c}6.98 \pm 0.15^{*} \\
(20.40)\end{array}$ & $\begin{array}{c}6.76 \pm 0.20^{* * *} \\
(24.10)\end{array}$ & $\begin{array}{c}7.04 \pm 0.18^{* * *} \\
(23.21)\end{array}$ & $\begin{array}{c}7.51 \pm 0.21^{* *} \\
(16.14)\end{array}$ \\
\hline $\begin{array}{l}\text { Ethyl acetate } \\
\text { fraction }\end{array}$ & 200 & $\begin{array}{c}7.84 \pm 0.55 \\
(10.63)\end{array}$ & $\begin{array}{c}7.43 \pm 0.63^{*} \\
(16.56)\end{array}$ & $\begin{array}{c}7.37 \pm 0.32^{* * *} \\
(19.54)\end{array}$ & $\begin{array}{c}7.67 \pm 0.34 * \\
(14.38)\end{array}$ \\
\hline $\begin{array}{l}n \text {-Butanol } \\
\text { fraction }\end{array}$ & 200 & $\begin{array}{c}7.07 \pm 0.261^{*} \\
(19.35)\end{array}$ & $\begin{array}{c}6.63 \pm 0.17 * * * \\
(25.52)\end{array}$ & $\begin{array}{c}6.70 \pm 0.22^{* * *} \\
(26.87)\end{array}$ & $\begin{array}{c}7.53 \pm 0.14 * \\
(15.89)\end{array}$ \\
\hline
\end{tabular}

Values are mean of 5 experiment \pm standard error (S.E.).

Data between parenthesis indicate the $\%$ of inhibition.

Differences with respect to the control group using student's t-test $\left({ }^{*} \mathrm{P}<0.05{ }^{* *} \mathrm{P}<0.01{ }^{* * * *} \mathrm{P}<0.001\right)$.

Table 5: Results of antipyretic activity of the different fractions on yeast-induced pyrexia in rats.

\begin{tabular}{|l|c|c|c|c|c||}
\hline \multirow{2}{*}{ Group } & $\begin{array}{c}\text { Dose } \\
\mathrm{mg} / \mathrm{Kg}\end{array}$ & \multicolumn{4}{|c|}{ Average rectal temperature $\left({ }^{\circ} \mathrm{C}\right) \pm \mathrm{S} . \mathrm{E} ., \mathrm{n}=5$} \\
\cline { 2 - 6 } & & $\mathrm{T}_{\mathrm{o}} \mathrm{hr}$ & $1 \mathrm{hr}$ & $2 \mathrm{hrs}$ & $3 \mathrm{hrs}$ \\
\hline Control & ----- & $37.9 \pm 0.21$ & $37.8 \pm 0.24$ & $37.9 \pm 0.20$ & $37.8 \pm 0.20$ \\
\hline Indomethacin & 8 & $38.0 \pm 0.12$ & $36.6 \pm 0.13^{* *}$ & $35.7 \pm 0.15^{* *}$ & $36.3 \pm 0.09^{* *}$ \\
\hline Total extract & 200 & $38.1 \pm 0.15$ & $36.6 \pm 0.24^{*}$ & $36.6 \pm 0.20^{* * *}$ & $37.2 \pm 0.20^{*}$ \\
\hline$n$-Hexane fraction & 200 & $38.0 \pm 0.17$ & $36.9 \pm 0.17$ & $36.3 \pm 0.15^{* * *}$ & $37.0 \pm 0.17^{* *}$ \\
\hline $\mathrm{CHCl}_{3}$ fraction & 200 & $38.1 \pm 0.18$ & $36.8 \pm 0.33$ & $36.5 \pm 0.19^{* * *}$ & $36.8 \pm 0.15^{* * *}$ \\
\hline EtOAc fraction & 200 & $38.1 \pm 0.14$ & $36.4 \pm 0.29^{* *}$ & $36.4 \pm 0.25^{* * *}$ & $36.9 \pm 0.12^{* * *}$ \\
\hline$n$-Butanol fraction & 200 & $38.0 \pm 0.18$ & $36.5 \pm 0.17^{* *}$ & $36.1 \pm 0.09^{* * *}$ & $36.5 \pm 0.07^{* * *}$ \\
\hline \hline
\end{tabular}

$\mathrm{T}_{\mathrm{o}}=$ average rectal temperature just before plant fractions or solvent injection.

Values are mean of 5 experiment \pm standard error (S.E.).

Differences with respect to the control group using student's t-test $\left({ }^{*} \mathrm{P}<0.05{ }^{* *} \mathrm{P}<0.01{ }^{* * *} \mathrm{P}<0.001\right)$.

Table 6: Results of the effect of different fractions on motor Co-ordination.

\begin{tabular}{|c|c|c|c|}
\hline \multirow{2}{*}{ Group } & \multirow{2}{*}{$\begin{array}{l}\text { Dose } \\
\mathrm{mg} / \mathrm{kg}\end{array}$} & \multicolumn{2}{|c|}{ Time on the rod $(\mathrm{sec}).($ mean $\pm \mathrm{SE}), \mathrm{n}=5$} \\
\hline & & $0.5 \mathrm{hr}$ & $1 \mathrm{hr}$ \\
\hline Control & (------- & $150 \pm 1.67$ & $150.1 \pm 2.1$ \\
\hline Total extract & 200 & $27.0 \pm 0.84 * * *$ & $24.6 \pm 3.27 * * *$ \\
\hline$n$-Hexane fraction & 200 & $111.0 \pm 4.12 * * *$ & $85.4 \pm 7.53 * * *$ \\
\hline Chloroform fraction & 200 & $120 \pm 5.23 * * *$ & $93.4 \pm 4.32 * * *$ \\
\hline Ethyl acetate fraction & 200 & $67.4 \pm 3.12 * * *$ & $28.8 \pm 2.82 * * *$ \\
\hline$n$-Butanol fraction & 200 & $34.4 \pm 2.06^{* * *}$ & $19.2 \pm 2.52 * * *$ \\
\hline
\end{tabular}

Values are mean of 5 experiment \pm standard error (S.E.).

Differences with respect to the control group using student's t-test $\left({ }^{* * *} \mathrm{P}<0.001\right)$. 
Table 7: Results of the effect of different fractions on pentylenetetrazole induced convulsion and death.

\begin{tabular}{|l|c|c|c|c||}
\hline \multicolumn{1}{|c|}{ Group } & $\begin{array}{c}\text { Dose } \\
\mathrm{mg} / \mathrm{kg}\end{array}$ & $\begin{array}{c}\text { Time of clonic } \\
\text { convulsion (min) } \\
(\mathrm{mean} \pm \text { S.E.), } \mathrm{n}=5\end{array}$ & $\begin{array}{c}\text { Time of tonic } \\
\text { convulsion }(\mathrm{min}) \\
(\mathrm{mean} \pm \text { S.E.) } \mathrm{n}=5\end{array}$ & $\begin{array}{c}\text { Time until death } \\
(\mathrm{min}) \\
(\mathrm{mean} \pm \text { S.E. }), \mathrm{n}=5\end{array}$ \\
\hline Control & ----- & 1 & $1.92 \pm 0.21$ & $2.31 \pm 0.12$ \\
\hline Standard & 5 & $3.50 \pm 0.18^{* *}$ & $10.32 \pm 0.31^{* *}$ & $14.21 \pm 0.21^{* *}$ \\
\hline Total extract & 200 & $3.51 \pm 0.32^{* *}$ & $12.11 \pm 0.43^{* *}$ & $17.51 \pm 0.21^{* *}$ \\
\hline$n$-Hexane fraction & 200 & $1.52 \pm 0.53^{*}$ & $2.13 \pm 0.21^{* *}$ & $2.63 \pm 0.56$ \\
\hline Chloroform fraction & 200 & $1.32 \pm 0.23$ & $1.91 \pm 0.12$ & $2.32 \pm 0.32$ \\
\hline EtOAc fraction & 200 & $1.12 \pm 0.45$ & $1.81 \pm 0.53$ & $2.01 \pm 0.23$ \\
\hline$n$-Butanol fraction & 200 & $1.31 \pm 0.21$ & $2.11 \pm 0.36$ & $2.82 \pm 0.32$ \\
\hline
\end{tabular}

Values are mean of 5 experiment \pm standard error (S.E.).

Differences with respect to the control group using student's t-test $\left({ }^{*} \mathrm{P}<0.05{ }^{* *} \mathrm{P}<0.01\right)$.

Table 8: Effect of total aqueous extract on $\mathrm{CCl}_{4}$ treated rats.

\begin{tabular}{|l|c|c|c|c|}
\hline \multicolumn{1}{|c|}{ Animal group } & GOT & GPT & Total lipid & Total bilirubin \\
\hline Control (Normal) & $23.2 \pm 0.860$ & $32.6 \pm 1.077$ & $84.8 \pm 2.835$ & $0.56 \pm 0.017$ \\
\hline $\mathrm{CCl}_{4}$ treated & $86.0 \pm 4.868$ & $48.8 \pm 1.772$ & $163.6 \pm 7.985$ & $1.11 \pm 0.083$ \\
\hline Aq. Ext. alone & $27.4 \pm 1.6$ & $34.0 \pm 1.414$ & $91.2 \pm 1.855$ & $0.59 \pm 0.020$ \\
\hline Aq. Ext. and $\mathrm{CCl}_{4}$ & $52.8 \pm 6.888^{* *}$ & $40.4 \pm 1.435^{* *}$ & $108.6 \pm 3.027 * *$ & $0.77 \pm 0.024 * *$ \\
\hline
\end{tabular}

Values are mean of 5 experiment \pm standard error (S.E.).

Differences with respect to the control group using student's t-test $\left({ }^{* *} \mathrm{P}<0.01\right)$.

Table 9: Results of GLC analysis of fatty acids methyl esters.

\begin{tabular}{|c|c|c|c|c|c|}
\hline Peak No. & Fatty acids & No. of carbons & No. of unsaturation & $\mathrm{R}_{\mathrm{t}} / \mathrm{min}$ & Relative area \% \\
\hline 1 & Lauric acid & 12 & 0 & 12.78 & 1.61 \\
\hline 2 & Myristic acid & 14 & 0 & 14.53 & 1.53 \\
\hline 3 & Unknown & ---- & ---- & 16.59 & 0.57 \\
\hline 4 & Palmetic acid & 16 & 0 & 18.50 & 28.49 \\
\hline 5 & Palmetoleic acid & 16 & 1 & 18.85 & 1.11 \\
\hline 6 & Unknown & ---- & ---- & 19.88 & 0.84 \\
\hline 7 & Unknown & ---- & ---- & 20.45 & 0.53 \\
\hline 8 & Stearic acid & 18 & 0 & 21.27 & 1.59 \\
\hline 9 & Oleic acid & 18 & 1 & 21.90 & 10.33 \\
\hline 10 & Unknown & ---- & ---- & 22.43 & 7.21 \\
\hline 11 & Linoleic acid & 18 & 2 & 23.30 & 12.96 \\
\hline 12 & Unknown & --- & --- & 24.51 & 18.66 \\
\hline 13 & Linolenic acid & 18 & 3 & 25.24 & 0.54 \\
\hline 14 & Unknown & ---- & ---- & 25.95 & 0.53 \\
\hline 15 & Behenic acid & 22 & 0 & 27.40 & 1.02 \\
\hline 16 & Erucic acid & 22 & 1 & 28.30 & 1.04 \\
\hline 17 & Unknown & --- & - & 30.06 & 0.90 \\
\hline 18 & Cerotic acid & 26 & 0 & 32.65 & 1.04 \\
\hline 19 & Unknown & --- & ---- & 33.20 & 0.84 \\
\hline 20 & Unknown & --- & ---- & 33.82 & 1.10 \\
\hline 21 & Unknown & ---- & ---- & 35.69 & 0.69 \\
\hline 22 & Unknown & ---- & ---- & 36.42 & 0.53 \\
\hline 23 & Unknown & ---- & ---- & 37.08 & 0.60 \\
\hline 24 & Unknown & ---- & ---- & 39.86 & 5.62 \\
\hline
\end{tabular}




\section{Acknowledgement}

The authors thanks Prof. Dr. Ahmed Othman, Professor of Pharmacology, Faculty of Medicine, Assiut University for his great help and assistance through the pharmacological studies.

\section{REFERENCES}

1- O. P. Sharma, "Plant Taxonomy", Tata Mc Graw-Hill LTD, New Delhi, India (1993).

2- G. H. M. Lawrence, "Taxonomy of Vascular Plants", $12^{\text {th }}$ Printing, MacMillan Co., New York (1968).

3- R. D. Meikle, "Flora of Cyprus", Vol. II, Bentham-Moxom Trust, Royal Botanic Gardens, London (1985).

4- L. H. Bailey, "The Standard Cyclopedia of Horticulture", $20^{\text {th }}$ Ed., Vol. I, the MacMillan Co., New York (1963).

5- H. Fischer, W. Jensen, S. R. Jensen, and B. J. Nielsen, "Eranthemoside, a new iridoid glucoside from Eranthemum pulchellum (Acanthaceae)", Phytochemistry, 26, 3353-3354 (1987).

6- L. D. Ismail, "3-methoxy vasicinone, an alkaloid was isolated for the first time from Eranthemum nervosum Acanthaceae", Az. J. Pharm. Sci., 27, 293-296 (2001).

7- A. R. Johnson and J. B. Davenport, "Biochemistry and Methodology of Lipids", John Wiley \& Sons, INC., New York (1971).

8- G. Nonaka, M. Minami, and I. Nishioka, "Studies on Rhubarb (Rhei rhizoma), stilbene glycosides", Chem. Pharm. Bull., 25, 2300-2305 (1977).

9- J. Leukowitsch, "Chemical Technology and Analysis of Oils, Fats and Waxes", MacMillan CO. London (1938).

10- W. G. Snedeor and C. W. Cochran, "Statistical Methods" $8^{\text {th }}$ Ed., Lowa state University Press, Lowa, USA (1989).

11- R. A. Turner, "Screening Methods in Pharmacology", Vol. I New York, Academic Press (1965).

12- C. A. Winter, E. A. Risley and G. W. Nuss, "Carrageenan-induced edema in hind paws of the rat as an assay for antiinflammatory drugs", Proc. Soc. Exp. Biol. Med., 111, 544-547 (1962).
13- S. O. A. Bamgbose and B. K. Noamesi, "Studies on Cryptolepine II: Inhibition of carragenan induced oedema by cryptolepine", Planta Med., 41, 392-396 (1981).

14- G. Bisignano, L. Iauk, S. Kirjavainen and E. M. Galati, "Anti-Inflammatory, analgesic, antipyretic and antibacterial activity of Astragalus siculus Biv", Pharm. Biol., 32, 400-405 (1994).

15- J. R. Boissier, P. Simon, M. Zaczinska and J. Fihelle, "Experimental study of a novel psychopharmacological ethylamino-6chloro-4-methyl-4-phenyl-4H-3,1-benzoxazine", Therapie, 27, 325-338 (1972).

16- R. Villar, M. R. Laguna, J. M. Calleja and I. Cadavid, "Effects of Skeletonema costatum extracts on the Central Nervous System”, Planta Med., 58, 398-404 (1992).

17- M. Nisar, I. Khan, S. U. Simjee, A. H.Gilani, Obaidullah and H. Perveen, "Anticonvulsant, analgesic and antipyretic activities of Taxus wallichiana Zucc", J. Ethnopharmacol., 116, 490-494 (2008).

18- R. Sallie, J. M. Tredger and R. William, "Drug and the liver", Biopharm. Drug Dis., 12, 251-259 (1991).

19- N. N. Qureshi, B. S. Kuchekar, N. A. Logade and M. A. Haleem, "Antioxidant and hepatoprotective activity of Cordia macleodii leaves", Saudi Pharmaceutical Journal, 17, 317-322 (2009).

20- G. S. Achliya, N. R. Kotagale, S. G. Wadodkar, and A. K. Dorle, "Hepatoprotective activity of panchagavyaghrita against $\mathrm{CCl}_{4}$ induced hepatotoxicity in rats", Ind. J. Pharmacol., 35, 308-311 (2003).

21- B. K. Chandan, A. K. Saxena, S. Shukla, N. Sharma, D. K. Gupta, K. A. Suri, J. Suri, M. Bhadauria and B. Singh, "Hepatoprotective potential of Aloe barbadensis Mill. against carbon tetrachloride induced hepato-toxicity", J. Ethnopharmacol., 111, 560-566 (2007).

22- J. B. Harborne, "Phytochemical Methods", Chapman and Hall LTD, $2^{\text {nd. }}$ Ed., London, New York (1984).

23- L. F. Fieser and M. Fieser, "Natural product related to phenanthrene", Reinhold Publishing Corp., $3^{\text {rd }}$ Ed., New York (1949). 
24- J. B. Harborne, T. J. Mabry and H. Mabry, "The flavonoids", Chapman and Hall Ltd., London (1976).

25- S. B. Mahato and A. P. Kundu, " ${ }^{13} \mathrm{C}$ NMR spectra of pentacyclic triterpenoids - A compilation and some salient features", review article, Phytochemistry, 37, 15171575 (1994).

26- N. S. Kumar, P. M. Muthukuda and M. I. M. Wazeer, "A lupenediol from Euonymus revolutus", ibid., 24, 1337-1340, (1985).

27- T. J. Mabry, K. R. Markham and M. B. Thomas, "The Systematic Identification of Flavonoids", Springer Verlage, New York, Heidelberg and Berlin (1970).

28- P. K. Agrawal, "Carbon-13 NMR of Flavonoids", Elsevier Science Publishing company Inc., New York (1989).

29- J. B. Harborne and T. J. Mabry, "The Flavonoids: Advances in Research", Chapman and Hall, London, New York (1982).

30- T. A. Giessman, "The Chemistry of Flavonoid Compounds", The MacMillan Co., New York (1969).

31- O. A. Ekabo, N. R. Farnsworth, T. Santisuk and V. Reutrakul, "A phytochemical investigation of Homalium ceylanicum", J. Nat. Prod., 56, 699-707 (1993).
32- M. Niwa,Y. Iwadare, Y. Wu and Y. Hirata, "Two new phenylpropanoid glycosides from Wikstroemia sikokiana", Chem. Pharm. Bull., 36, 1158-1161 (1988).

33- M. S. Kamel, "Acylated phenolic glycosides from Solenostemma argel", Phytochemistry, 62, 1247-1250 (2003).

34- M. Sugiyama, E. Nagayama and M. Kikuchi, "Lignan and phenylpropanoid glycosides from Osmanthus asiaticus", ibid., 33, 1215-1219 (1993).

35- M. D. Greca, M. Ferrara, A. Fiorentino, P. Monaco and L. Previtera, "Antialgal compounds from zantedeschia aethiopica", ibid., 49, 1299-1304 (1998).

36- M. Ono, Y. Ito, T. Ishikawa, J. Kitajima, Y. Tanaka, Y. Niiho and T. Nohara, "Five new monoterpene glycosides and other compounds form Foeniculi Fructus (Fruit of Foeniculum vulgare MILLER", Chem. Pharm. Bull., 44, 337-342 (1996).

37- P. K. Agrawal, "NMR spectroscopy in the structural elucidation of oligosaccharides and glycosides", Phytochemistry, 31, 3307-3330 (1992).

38- J. B. Harborne, "The Flavonoids: Advances in Research since 1986", Chapman and Hall, London (1994). 